\title{
EVALUATION OF TREATMENT BRONCHODILATORS AND CORTICOSTEROIDS IN COPD INPATIENT IN HOSPITALS DR. MOEWARDI SURAKARTA JANUARY 2016-JUNE 2017
}

\author{
Lusia Murtisiwi ${ }^{1}$, Endang Widhiyastuti ${ }^{2}$, Dwi Muji Rohati ${ }^{3}$ \\ ${ }^{1}$ Program Studi S1 Farmasi, Sekolah Tinggi Ilmu Kesehatan Nasional, Surakarta \\ ${ }^{2}$ Program Studi DIV Teknologi Laboratorium Medik, Sekolah Tinggi IImu Kesehatan Nasional, Surakarta \\ ${ }^{3}$ Program Studi DIII Farmasi, Sekolah Tinggi Ilmu Kesehatan Nasional, Surakarta \\ Corresponding \\ author : \\ lusia.murtisiwi@stikesnas.ac.id
}

\begin{abstract}
Chronic Obstructive Pulmonary Disease (COPD) is one of the cause of mortality and morbidity in worldwide. This study aims to determine the pattern of treatment of bronchodilators with or without corticosteroids and their effects on changes carbon dioxide pressure in blood $\left(\mathrm{PCO}_{2}\right)$ and oxygen pressure in blood $\left(\mathrm{PO}_{2}\right)$ in COPD patients of inpatient in RSUD Dr. Moewardi Surakarta January 2016-June 2017. This research is a retrospective descriptive research design, data collecting by tracking medical records patients with 195 samples. The results showed that treatment of COPD patient using single bronchodilator of $30,8 \%$, bronchodilator combination of $57,1 \%$, bronchodilator combination with corticosteroid of $1 \%$ and corticosteroid equal to $91,3 \%$.Effect of bronchodilator treatment without corticosteroids on changes in the largest largest $\mathrm{PCO}_{2}$ change of $14.8 \%$, the smallest change in $\mathrm{PCO}_{2} 5.9 \%$, the largest $\mathrm{PO}_{2}$ change was $19 \%$, the smallest $\mathrm{PO}_{2}$ change was $5.6 \%$, whereas in patients who received bronchodilator treatment with corticosteroids there was the largest $\mathrm{PCO}_{2}$ change of $87.4 \%$, the smallest $\mathrm{PCO}_{2}$ change of $0 \%$, the largest $\mathrm{PO}_{2}$ changeby $75.7 \%$, the smallest change in $\mathrm{PO}_{2}$ is $0.13 \%$.
\end{abstract}

Keywords : COPD, bronchodilator, corticosteroid, $\mathrm{PCO}_{2}, \mathrm{PO}_{2}$

\section{Introduction}

Chronic Obstructive Pulmonary Disease (COPD) is one of the causes of mortality and morbidity in the world. According to the 2018 Global Initiative for Chronic Obstructive Lung Disease (GOLD), COPD is currently the fourth leading cause of death in the world but is projected to be the $3^{\text {rd }}$ leading cause of death by 2020. The incidence of COPD can increase with an increase in the number of smokers because $90 \%$ of COPD sufferers are smokers or former smokers. Based on the results of a survey of non-communicable diseases, the Directorate General of PPM and PL in 5 provincial hospitals in Indonesia, namely West Java, Central Java, East Java, Lampung and South Sumatra in 2004, first-rate COPD contributed $35 \%$ to morbidity, followed by asthma bronchial by $33 \%$, lung cancer by $30 \%$ and others by $2 \%$ (PDPI, 2011).

Chronic Obstructive Pulmonary Disease (COPD) is characterized by persistent respiratory symptoms and airflow limitation that is due to airway Volume 1 Issue 1 (2018) and/or alveolar abnormalities usually caused by significant exposure to noxious particles or gases. The classification of airflow limitation severity of COPD can shown based on post-bronchodilator $\mathrm{FEV}_{1}$ with spirometry test. According to 2018 GOLD to date, there is no conclusive clinical trial evidence that any existing medications for COPD modify the long-term decline in lung function. Bronchodilators are one of the drugs recommended for the treatment of COPD (GOLD, 2018; PDPI, 2011). Combination of a long beta 2 -agonist and an inhaled corticosteroid may benefit for patients with persistent exacerbations (GOLD, 2018), but should balance the potential benefits of inhaled steroids in COPD against the potential side effects (Yang, et al., 2012).

Based on data taken from the health profile of the city of Surakarta in 2014, the prevalence of COPD in Dr. Moewardi as many as 578 patients. Research has been done on therapeutic patterns and costs for COPD patients, but evaluations of bronchodilator and corticosteroid treatment have never been carried out. Based on the above problems, 
it is necessary to evaluate bronchodilator treatment with or without corticosteroids in COPD patients in the inpatient installation of Dr. Moewardi Surakarta and its effect on changes in carbon dioxide pressure in the blood $\left(\mathrm{PCO}_{2}\right)$ and blood oxygen pressure $\left(\mathrm{PO}_{2}\right)$ in COPD patients in the inpatient installation of Dr. Moewardi Surakarta.

\section{Methods}

This research is a descriptive research. Retrospective data collection was carried out by tracing the treatment records of COPD patients who were hospitalized in Dr. Moewardi Surakarta from January 2016-June 2017.The sample size was determined based on the Slovin formula, obtained 190 patients. Sampling was taken by purposive sampling. Inclusion criteria: inpatient installation patients at Dr. Moewardi Surakarta,patients with COPD diagnosis or from spirometry marked with $\mathrm{FEV}_{1} / \mathrm{FVC}<0.70$, patients who received bronchodilator treatment (beta2-agonist, anticholinergic and methyl xanthine) alone or in combination with or without corticosteroids, and adult patients aged $\geq 18$ years.Exclusion criteria: patients with a diagnosis of asthma.

Analysis

Univariate analysis was used to obtain an overview of the frequency distribution and proportion of the variables studied such as age, sex, occupation, smoking history, spirometry, clinical symptoms, comorbidity, treatment, and effects of treatment on changes in $\mathrm{PCO}_{2}$ and $\mathrm{PO}_{2}$ levels.

\section{Results and Discussion}

\section{Patients characteristics}

1. Age

Age distribution of COPD patients in the inpatient installation of Dr. Moewardi Surakarta in January 2016-June 2017 is shown in table

\begin{tabular}{ccc}
\multicolumn{2}{c}{ Table1.Age distribution of patients } \\
\hline \multirow{2}{*}{ Age } & \multicolumn{2}{c}{$\mathrm{n}=195$} \\
\cline { 2 - 3 } & $\mathrm{n}$ & $\%$ \\
\hline $18-44$ years & 5 & 2,6 \\
$45-54$ years & 50 & 25,1 \\
$55-64$ years & 76 & 39 \\
$65-74$ years & 56 & 28,7 \\
$>75$ years & 195 & 100 \\
\hline Amount & $\mathrm{n}:$ number of patients
\end{tabular}

Based on the results of the study found patients in the age range of 18-44 years as many as 5 people $(2.6 \%)$, aged $45-54$ years obtained as many as 8 people $(4.1 \%)$, aged $55-64$ years 50 people $(25.6 \%$ ), age $65-74$ years 76 people (39\%) and age $>75$ years 56 people $(28.7 \%)$. From these data it can be seen that the greatest prevalence of COPD occurs in the age range $65-74$ years which reaches $39 \%$ of the total sample. Based on GOLD (2018), airway obstruction is more common at the age of over 40 years and the highest is at the age of over 60 years. This is in line with research conducted by Permatasari (2016) most COPD patients in the age range 55-64 years $(56.2 \%)$,also supported by Naser's study (2016) the largest COPD age group in the age range of 60 years and over is as much as 55\%. Decreased lung function will be accelerated in people who continue to smoke after more than 45 years of age (Suradi, 2007).

The maximum function of the respiratory system is reached at the age of 20-25 years, after which there is a progressive decrease in lung capacity in connection with aging. Physiological changes in COPD are responsible for progressive abnormalities in elderly patients. But many anatomical and physiological changes in COPD also appear in the Volume 1 Issue 1 (2018) lungs of elderly patients who do not smoke. This shows that the aging process is a factor that contributes to the incidence of COPD (Hanania, etal., 2010).

\section{Gender}

Distribution of COPD patients in the inpatient installation of Dr. Moewardi Surakarta in January 2016-June 2017 based on gender shown in table 2. Based on the results of the study, COPD patients with male gender showed greater numbers than women. Gender plays a role in determining whether a person is more susceptible to COPD or not. From the results of this study obtained the number of male patients as many as 170 people $(87.2 \%)$ and the female sex as many as 25 people $(12.8 \%)$. Judging from the aspect of risk factors for smoking habits, patients with male gender have a higher risk of developing COPD. Based on Riskesdas (2010) the prevalence of male smokers in Indonesia is 16 times higher than women. This is supported by the results of Permatasari's (2016) study of male patients dominating COPD (96.9\%). 
Table 2.Gender distribution of patients

\begin{tabular}{ccc}
\hline \multirow{2}{*}{ Gender } & \multicolumn{2}{c}{$\mathrm{n}=195$} \\
\cline { 2 - 3 } & $\mathrm{N}$ & $\%$ \\
\hline Male & 170 & 87,2 \\
Female & 25 & 12,8 \\
\hline Amount & 195 & 100 \\
\hline \multicolumn{3}{c}{ n:number of patients }
\end{tabular}

2. Job

In table 3 shows the job of COPD patients in the inpatient installation of Dr. Moewardi Surakarta from January 2016-June 2017.

There were 25 COPD patients who has complete job data. The most occupations of COPD patients are farmers and retirees with a proportion of $24 \%$ each. Data on the work of carpenters and pedicab drivers shows that each proportion is $8 \%$. In the data of work no job (housewives) it is stated that they use firewood for cooking. A cross-sectional observational study showed that self-reported exposure to workplace dust and fumes in men and women is associated with airflow obstruction, respiratory symptoms, more emphysema, and gas trapping similarly in men and women (Marchetti, et al., 2014).
According to Oemiati (2013) one of the risk factors for COPD is exposure of particles from smoking, indoor pollution, outdoor pollution and pollution in the workplace. Indoor pollution such as cooking with biomass materials with poor kitchen ventilation such as exposed to wood fuel or fuel oil smoke is estimated to contribute up to $35 \%$ (Reilly, 2008). WHO reports that indoor pollution is responsible for the deaths of 1.6 million people each year (WHO, 2008). Outdoor pollution such as combustion smoke, factory or mining materials. Pollution in the workplace such as organic dust, textile industry, iron and steel industry, wood industry, paint or ink manufacturing chemicals, is estimated at $19 \%$ (Di Pede, 2002).

Tabel 3. Characteristics of COPD patients

\begin{tabular}{ccc}
\hline \multirow{2}{*}{ Job } & \multicolumn{2}{c}{$\mathrm{n}=25$} \\
\cline { 2 - 3 } & $\mathrm{n}$ & $\%$ \\
\hline Farmer & 6 & 24 \\
Carpenter & 2 & 8 \\
Pedicab driver & 2 & 8 \\
Retired & 6 & 24 \\
No job & 4 & 16 \\
Entrepreneur & 5 & 20 \\
\hline Amount & 25 & 100 \\
\hline n: number of patients with complete job data
\end{tabular}

3. Smoking history

Distribution of smoking history of COPD patients in the inpatient installation of

\begin{tabular}{ccc} 
Table 4.Distribution of patient smoking history \\
\cline { 2 - 3 } Smoking history & \multicolumn{2}{c}{$\mathrm{n}=111$} \\
\cline { 2 - 3 } & 75 & $\% 7,6$ \\
\hline Active smokers & 11 & 9,9 \\
Ex-smokers & 25 & 22,5 \\
Non-smokers & 111 & 100 \\
\hline Amount & n: number of patients with complete smoking history data
\end{tabular}

Based on the results of the study obtained 111 medical records of patients who contain smoking history. From these data can be calculated patients with a history of active smokers as many as 75 people $(67.6 \%)$, ex-
Dr. Moewardi Surakarta from January 2016-June 2017 is shown in table 4. smokers 11 people (9.9\%), non-smokers 25 people $(22.5 \%)$. The relationship between cigarettes and COPD is a dose response relationship, which is seen from the length of smoking habits and the number of cigarettes 
consumed every day it will risk greater disease (PDPI, 2011). The results of this study are in line with the research conducted by Naser (2016) history smoking COPD patients occupy the largest percentage. According to the 2011 National Socio-Economic Survey (SUSENAS) data, $67.4 \%$ of adult men in Indonesia are active smokers (BPS, 2011).

\section{Spirometry Test Value and Clinical Symptoms of COPD Patients}

Spirometry test value shows the severity of COPD which is divided into mild, moderate, heavy and very severe. The degree of severity of COPD patients is determined based on $\mathrm{FEV}_{1} /$ FVC $<70 \%$ which means that there is an obstruction using a spirometer (GOLD, 2018). Clinical symptoms of COPD patients consist of shortness of breath, coughing with phlegm, coughing without phlegm, and wheezing.

1. Spirometry test value

Table 5 shows the distribution of the severity of COPD patients in the inpatient installation of Dr. Moewardi Surakarta from January 2016-June 2017.

Table5. Distribution of patient severity

\begin{tabular}{|c|c|c|c|}
\hline \multirow{2}{*}{ Severity } & \multirow{2}{*}{ Value of Sprirometry Test } & \multicolumn{2}{|c|}{$\mathrm{n}=34$} \\
\hline & & $\mathrm{n}$ & $\%$ \\
\hline Mild & $\mathrm{FEV}_{1} / \mathrm{FVC}<70 \%$ & 10 & 29,4 \\
\hline & $\mathrm{FEV}_{1} \geq 80 \%$ predicted & & \\
\hline Moderate & $\mathrm{FEV}_{1} / \mathrm{FVC}<70 \%$ & 22 & 64,7 \\
\hline Severe & $\begin{array}{c}50 \% \leq \mathrm{FEV}_{1}<80 \% \text { predicted } \\
\mathrm{FEV}_{1} / \mathrm{FVC}<70 \% \\
30 \% \leq \mathrm{FEV}_{1}<50 \% \text { predicted }\end{array}$ & 2 & 5,9 \\
\hline Very severe & $\begin{array}{c}\mathrm{FEV}_{1} / \mathrm{FVC}<70 \% \\
\mathrm{FEV}_{1}<30 \% \text { predicted }\end{array}$ & 0 & 0 \\
\hline Amount & & 34 & 100 \\
\hline
\end{tabular}

There were 34 patients who had complete spirometry test data from 195 COPD patients. Based on the results of the study showed that patients who experienced mild obstruction were 10 people $(29.4 \%)$, moderate obstruction 22 people $(64.7 \%)$ and those with severe obstruction 2 people $(5.9 \%)$, and no patients who experienced very severe obstruction. The classification of severity of COPD can be used to determine the treatment of appropriate COPD patients (PDPI, 2011). In line with the research conducted by Permatasari (2016) at Dr. RSUD Soetomo Surabaya, the greatest severity of COPD patients is in moderate obstruction by $50 \%$.

\section{Clinical symptoms}

In table 6 shows the distribution of clinical symptoms of COPD patients in the inpatient installation of Dr. Moewardi Surakarta from January 2016 - June 2017.

Table 6. Distribution of comorbidities of COPD patients

\begin{tabular}{ccc}
\hline \multirow{2}{*}{ Comorbidities } & \multicolumn{2}{c}{$\mathrm{n}=171$} \\
\cline { 2 - 3 } & $\mathrm{n}$ & $\%$ \\
\hline Cardiovascular disease & 81 & $47,4 \%$ \\
Respiratory disease & 59 & $34,5 \%$ \\
Others & 31 & $18,1 \%$ \\
\hline Amount & 171 & 100 \\
\hline n: number of patients with comorbidity
\end{tabular}

A total of 81 patients $(47.4 \%)$ COPD had comorbid cardiovascular disease which included Heart Failure Hypertension (HHF), Congestive Heart Failure (CHF), Old Myocardial Infarction (OMI), arithmia, cardiomegaly, Acute Decompensated Heart Failure (ADHF), hypertension and stroke. In addition to cardiovascular disease, respiratory diseases such as pneumonia, tuberculosis, lung cancer, laryngeal cancer and asthma are found in the proportion of $34.5 \%$. In other comorbidities, there were $18.1 \%$ of diseases such as diabetes mellitus and gastritis.

Cardiovascular disease can be increased due to systemic inflammation caused by COPD which includes atherosclerosis, ventricular dysfunction, systemic heart disease, stroke, hypertension, chronic heart failure, sudden cardiac death (Sin DD, et al., 2006). Vanfletern et al. (2013) reported the largest five percentages 
of comorbidity in COPD were hyperglycemia (54\%), atherosclerosis (53\%), hypertension $(48 \%)$, dyslipidemia $(36 \%)$ and osteoporosis $(31 \%)$. The role of systemic inflammation is very important in the pathogenesis of comorbidities in COPD. Various risk factors for COPD (such as smoking and old age) as well as components of the metabolic syndrome (dyslipidemia, obesity and hypertension) using a systemic inflammatory pathway can cause various comorbidities (Kulsum, 2016).

\section{Bronchodilator and Corticosteroid Treatment}

In table 7 shows the distribution of treatment proportions of COPD patients in the inpatient installation of Dr. Moewardi Surakarta from January 2016-June 2017.

Table 7. Distribution of the proportion of treatment for COPD patients

\begin{tabular}{ccc}
\hline Treatment & $\mathrm{n}$ & $\%$ \\
\hline $\begin{array}{c}\text { Single bronchodilator } \\
\text { Bronchodilator } \\
\text { combination }\end{array}$ & 60 & $17 \%$ \\
$\begin{array}{c}\text { Bronchodilator with } \\
\text { corticosteroids } \\
\text { Corticosteroids }\end{array}$ & 2 & $32 \%$ \\
\hline Amount & 178 & $50,4 \%$ \\
\hline $\mathrm{n}:$ amount of treatment & 353 \\
\hline
\end{tabular}

The treatment distribution of COPD patients here is separated based on the use of a single bronchodilator, combination bronchodilator, bronchodilator and corticosteroids, and corticosteroids. Based on the results of the study showed that patients get one or more treatment therapies. The most proportion of treatment for COPD patients is corticosteroid use in the form of injection of $50.4 \%$. The most commonly used corticosteroid is methyl prednisolone through an injection form. Corticosteroids are used when an acute exacerbation occurs which serves to suppress inflammation that occurs either in oral form or intravenous injection (PDPI, 2011). According to Senior and Anthonisen (1998) that in COPD patients have improved pulmonary function after the use of anti-inflammatory methyl prednisolone corticosteroids.

In combination treatment therapy, the proportion of use was 115 patients. The drug used was a combination of fenoterol (berotec): ipratropium (atrovent) in 105 patients and a combination of salbutamol: ipratropium (combivent) in 8 patients. These two combinations of bronchodilators are a combination of the Short-acting beta2-agonist (SABA) group: Short-acting anticholinergic agent (SAMA). In addition it is also used a combination of formoterol: budesonide which is a group of Long-acting beta 2 -agonists (LABA): corticosteroids in 2 patients. All combinations of these drugs are used through the Nebuliser route. Nebulizer can be used to treat acute exacerbations. Besides that the use of combination drugs is simpler and makes it easier for sufferers (PDPI, 2011).

For the treatment of single bronchodilators that are often used are methyl xanthine (aminophylline) and SABA (salbutamol) via injection routes (drip) with a proportion of use of $17 \%$. Injection or drip forms can be used to treat acute exacerbations (PDPI, 2011).

\section{Effects of Treatment on Changes in Levels of $\mathrm{PCO}_{2}$ and $\mathrm{PO}_{2}$}

Based on the results of the study obtained 51 COPD patients who underwent blood gas analysis, 2 patients received bronchodilator treatment without corticosteroids and 49 patients received bronchodilator treatment with corticosteroids.

1. Bronchodilator treatment without corticosteroids

Bronchodilators that are intended in this study are anticholinergics, beta 2 agonists and methyl xanthine, while those without corticosteroids mean that patients do not get corticosteroid treatment either in the form of injection, inhalation or oral during blood gas analysis.

In table 8 can be seen the largest and smallest percentage changes in levels of $\mathrm{PCO}_{2}$ and $\mathrm{PO}_{2}$ in bronchodilator treatment without corticosteroids in COPD patients. 
Table 8. The largest and smallest percentage changes in $\mathrm{PCO}_{2}$ and $\mathrm{PO}_{2}$ levels in bronchodilator treatment without corticosteroids

\begin{tabular}{llccc}
\hline Level & Changes & Pre & Post & $\%$ \\
\hline \multirow{2}{*}{$\mathrm{PCO}_{2,(\mathrm{mmHg})}$} & Largest & 62 & 54 & $14,8 \%$ \\
\cline { 2 - 5 } & Smallest & 49,8 & 47 & $5,9 \%$ \\
\hline \multirow{2}{*}{$\mathrm{PO}_{2,(\mathrm{mmHg})}$} & Largest & 96,4 & 119 & $19 \%$ \\
\cline { 2 - 5 } & Smallest & 136 & 144 & $5,6 \%$ \\
\hline
\end{tabular}

Based on the results of this study, the highest change in $\mathrm{PCO}_{2}$ levels was $14.8 \%$ from $62 \mathrm{mmHg}$ to $54 \mathrm{mmHg}$, while the smallest was $5.9 \%$ from $49.8 \mathrm{mmHg}$ to $47 \mathrm{mmHg}$. The biggest change in $\mathrm{PO}_{2}$ level was 19\% from 96.4 $\mathrm{mmHg}$ to $119 \mathrm{mmHg}$, while the smallest was $5.6 \%$ from $136 \mathrm{mmHg}$ to $144 \mathrm{mmHg}$. The therapeutic treatment obtained by this patient is a combination of fenoterod bronchodilator: ipatropium by nebulizer.

2. Bronchodilator treatment with corticosteroids The percentage change in $\mathrm{PCO}_{2}$ and $\mathrm{PO}_{2}$ levels in bronchodilator treatment with corticosteroids can be seen in table 9 .

Table 9. The largest and smallest percentage changes in $\mathrm{PCO}_{2}$ and $\mathrm{PO}_{2}$ levels in bronchodilator treatment with corticosteroids

\begin{tabular}{llccc}
\hline Level & Changes & Pre & Post & $\%$ \\
\hline \multirow{2}{*}{$\left.\mathrm{PCO}_{2,(\mathrm{mmHg})}\right)$} & Largest & 77,6 & 41,4 & $87,4 \%$ \\
\cline { 2 - 5 } & Smallest & 32 & 32 & $0 \%$ \\
\hline \multirow{2}{*}{$\mathrm{PO}_{2,(\mathrm{mmHg})}$} & Largest & 88,3 & 296,3 & $75,5 \%$ \\
\cline { 2 - 5 } & Smallest & 156,8 & 157 & $0,13 \%$ \\
\hline
\end{tabular}

Based on the results of the study, the largest change in $\mathrm{PCO}_{2}$ levels was $87.4 \%$ from $77.6 \mathrm{mmHg}$ to $41.4 \mathrm{mmHg}$, the treatment therapy obtained by this patient included a combination of fenoterol nebulizer: ipatropium, aminophylline injection and methyl prednisolone injection. The smallest level of $\mathrm{PCO}_{2}$ was $0 \%$ from $32 \mathrm{mmHg}$ but did not give any changes at the end of the blood gas analysis.

At the highest change in $\mathrm{PO}_{2}$ levels was $75.5 \%$ from $88.3 \mathrm{mmHg}$ to $296.3 \mathrm{mmHg}$, these patients received treatment therapy which included a combination of fenoterol: ipratropium nebulizer and methyl prednisolone injection. While the smallest $\mathrm{PO}_{2}$ level is $0.13 \%$ from $156.8 \mathrm{mmHg}$ to $157 \mathrm{mmHg}$.

Research that shows the effect of corticosteroids on changes in $\mathrm{PCO}_{2}$ and $\mathrm{PO}_{2}$ levels, as was done by Rodrigues-Roisin (2005), namely in a comparative study the use of budesonide corticosteroid nebulizer with oral prednisone showed a small but significant increase in $\mathrm{PO}_{2}$ in the prednisone group and a decrease in $\mathrm{PCO}_{2}$ in both groups.

Based on Senior and Anthonisen (2009) and Rodrigues-Roisin (2005) studies it can be concluded that it was proven that after the use of corticosteroid anti-inflammatory drugs in COPD patients gave improvement in pulmonary function, thus affecting the levels of $\mathrm{PCO}_{2}$ and $\mathrm{PO}_{2}$. The results of this study are in accordance with research conducted by Senior and Volume 1 Issue 1 (2018)
Anthonisen (2009) and Rodrigues-Roisin (2005), because between the results of bronchodilator treatment with or without corticosteroids can increase levels of $\mathrm{PO}_{2}$ and reduce levels of $\mathrm{PCO}_{2}$ in the blood, although the data changes the smallest $\mathrm{PCO}_{2}$ bronchodilator treatment with corticosteroids showed no changes $(0 \%)$, but the $\mathrm{PO}_{2}$ levels showed an increase. Inhaled long acting beta2-agonists and corticosteroid combination treatment produces better control symptoms and lung function (Calverley, et al., 2003), but should balance the potential benefits of inhaled steroids in COPD against the potential side effects (Yang, et al., 2012).

\section{Conclusion}

The results show that Drug use in COPD patients hospitalized for COPD in Dr.Moewardi Hospital, respectively, single bronchodilator by $17 \%$, combination bronchodilator by $32 \%$, combination bronchodilator with corticosteroids by $0.6 \%$, and corticosteroids by $50.4 \%$. There were differences in changes in initial and final $\mathrm{PCO}_{2}$ levels between patients who received bronchodilator treatment without corticosteroids with patients who received bronchodilator treatment with corticosteroids, in patients who received bronchodilator treatment without corticosteroids there was the largest $\mathrm{PCO}_{2}$ change of $14.8 \%$, the smallest change in 
$\mathrm{PCO}_{2} 5.9 \%$, the largest $\mathrm{PO}_{2}$ change was $19 \%$, the smallest $\mathrm{PO}_{2}$ change was $5.6 \%$, whereas in patients who received bronchodilator treatment with corticosteroids there was the largest $\mathrm{PCO}_{2}$ change of $87.4 \%$, the smallest $\mathrm{PCO}_{2}$ change of $0 \%$, the largest $\mathrm{PO}_{2}$ changeby $75.7 \%$, the smallest change in $\mathrm{PO}_{2}$ is $0.13 \%$.

\section{References}

Badan Pusat Statistik (BPS), 2011, Survei Sosial Ekonomi Nasional (SUSENAS), Badan Penelitian dan Pengembangan Kesehatan, Jakarta.

Calverley, P., Pauwels, R., Vestbo, J., Jones, P., Pride, N., Gulsvik, A., Anderson, J., Maden, C., 2003, Combined salmeterol and fluticasone in the treatment of chronic obstructive pulmonary disease: a randomised controlled trial,Lancet, 361(9356):44956.

Di Pede, C., Viegi, G., 2002, Chronic Obstructive Lung Disease and Occupational Exposure, Current Opinion in Allergy Clinical Immunology, 2(2):115-121.

Global Initiative for Chronic Obstructive Lung Disease (GOLD), 2018, Global Strategy for the Diagnosis, Management, and Prevention of Chronic Obstructive Pulmonary Disease (2018 Report), National Institutes of Health, Lung and Blood Institute, USA.

Hanania, N.A., Sharma, G., Sharafkhaneh, A., 2010, COPD in the Elderly Patient, Semin Respir Crit Care Med, 31(5) : 596606.

Kulsum, I.D., Yunus, F., 2016, Sindrom Metabolik pada Penyakit Paru Obstruktif Kronik (PPOK), J Respir Indo Vol. 36 No. 1.

Marchetti, N., Garshick, E., Kinney, G.L., McKenzie, A., Stinson, D., Lutz, S.M., Lynch, D.A., Criner, G.J, Silverman, E.K., Crapo, J.D., 2014, Association between Occupational Exposure and Lung Function, Respiratory Symptoms, and High-Resolution Computed Tomography Imaging in
COPDGene, Am J Respir Crit Care Med, Vol 190, Iss 7, pp 756-762.

Naser, F.E., Medison, I., Erly, 2016, Gambaran Derajat Merokok Pada Penderita PPOK di Bagian Paru RSUP Dr. M. Djamil, Jurnal Kesehatan Andalas.

Oemiati, R., 2013, Kajian Epidemiologis Penyakit Paru Obstruktif Kronik (PPOK), Media Litbangkes Vol. 23 No. 2.

Perhimpunan Dokter Paru Indonesia (PDPI), 2011, Penyakit Paru Obstruksi Kronik (PPOK), Pedoman Praktis dan Penatalaksanaan di Indonesia, Perhimpunan Dokter Paru Indonesia, Jakarta.

Permatasari, C.Y., 2016, Study Penggunaan Kortikosteroid pada Pasien Penyakit Paru Obstruksi Kronik di RSUD Dr. Soetomo Surabaya, Skripsi, Fakultas Farmasi Universitas Airlangga, Surabaya.

Reilly, K.H., Gu, D.F., Duan, X.F., Wu, X., Chen, C.S., et al, 2008, Risk Factors for COPD mortality in Chinese adult, Am Journal of Epidemiol Vol 167 issue 8, p.998-1004.

Rodriguez-Roisin, R., 2005, COPD Exacerbations. 5: Management, Review Series. Thorax, Hospital Clinic, Barcelona.

Senior, R.M. and Anthonisen, N.R., 1998, Chronic Obstructive Pulmonary Disease (COPD), Am J Respir Crit Care Med, Vol 157, p S139-S147, The America Thoracic Society.

Sin, D.D., Anthonisen, N.R., Soriano, J.B., and Agusti, A.G., 2006, Mortality in COPD: role of comorbidities, Eur Respir J, 28: 1245-1257.

Suradi, 2007, Pengaruh Rokok pada Penyakit Paru Obstruktif Kronik (PPOK) Tinjauan Patogenesis, Klinis dan Sosial, Pidato Pengukuban Guru Besar Pulmonologi dan Ilmu Kedokteran Respirasi, Fakultas Kedokteran Universitas Sebelas Maret, Surakarta. 
Vanfleteren, L.E., et al., 2013, Clusters of Comorbidities Based on Validated Objective Measurements and Systemic Inflammation in Patient with Chronic Obstructive Pulmonary Disease, $A m \mathrm{~J}$ Respir Crit Care Med, 187(7):668-71.
World Health Organization (WHO), 2008, World Health Statistics, Geneva.

Yang, I.A, Clarke, M.S., Sim, E.H., Fong, K.M., 2012, Inhaled corticosteroids for stable chronic obstructive pulmonary disease, Cochrane Database Syst Review, 7: CD002991. 